\title{
KASVATUKSEN KAUTTA OMAEHTOISUUTEEN
}

Filosofian tohtori Koson Srisang on kotoisin pienestä Nalaon kylästä Koillis-Thaimaassa. Hänen vanhempansa olivat luku- ja kirjoitustaidottomia köyhiä maatyöläisiä.

Srisang kertoo lapsuudestaan: hän tuli jo lapsena tuntemaan, mitä köyhyys, kärsimys, sorto ja ulkopuolisuus merkitsevät käytännössä. Niinpä monissa yliopistoissa sekä kotimaassaan että maailmalla opiskellut Srisang haluaakin nyt palauttaa saamansa tiedon ja kokemukset syntymäkyläänsä ja jäädä sinne pysyvästi toteuttamaan perustamaansa projektia.

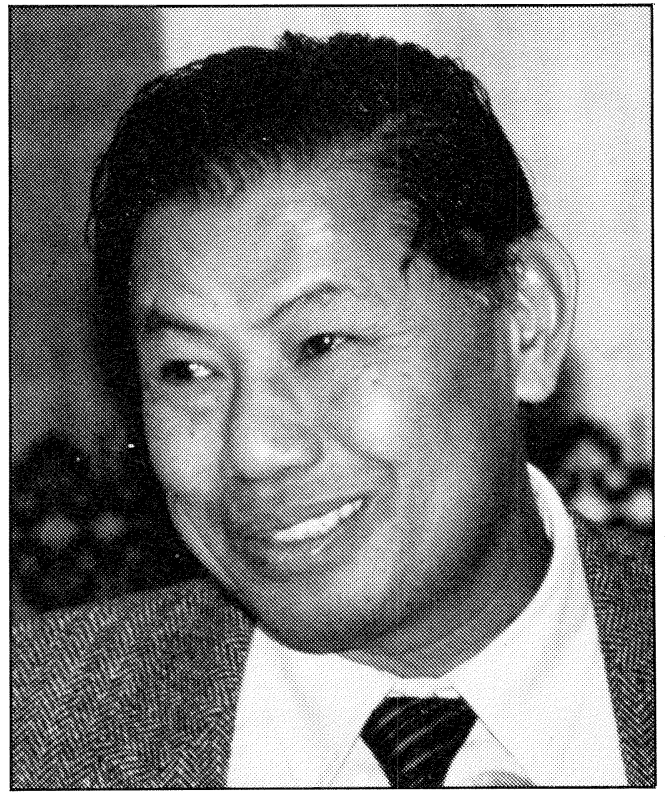

Koson Srisang vieraili viïme kesänä Meeting in Finland -seminaarissa, jossa etsittiin kasvatuksen keinoja kriittisen kansalaisuuden kautta demokratiaan.

\section{Tohtori Koson Srisangin ajatuksia thaimaalaisen}

\section{kyläinstituutin toiminnasta}

Hänen kyläprojektinsa VITAL käynnistyi vuonna 1987. Sen paikallisesti tunnettu nimi on Yaw Paw, mikä merkitsee 'Nuoruus itselle Luota itseesi -projekti'". Sen perusajatuksia on niin henkisen kuin aineellisenkin omaisuuden jakaminen. Kyläläiset - tässä tapauksessa nuoret - oppivat selviytymisen strategiaa maailmassa, joka ei ole rakennetțu köyhiä varten. Tavoitteena on palauttaa kyläyhteisö sykkiväksi jälleen, palauttamalla sen kulttuurinen identiteetti. Koson pitääkin omaa elämäntarinaansa ja projektia saman kolikon eri puolina.
Koson Srisangin Nanaon kyläprojektin ytimenä on kyläinstituutti (Village Institute for Training and Alternative Living). Se on tietynlainen sisäoppilaitos, jossa opiskelee köyhien perheiden lapsia ja nuoria, iältään 13-18 -vuotiaita. Opiskelijat asuvat ja työskentelevät yhdessä, syövät ja laulavat, ja kuten professori asian ilmaisee, joskus myös itkevät yhdessä.

' 'Thaimaalainen kasvatusjärjestelmä suosii rikkaita, köyhillä ei ole varaa kustantaa lapsiaan kouluun. Lisäksi oppisisällöt ja opetusmenetel- 
kansanperinteeseen ja juurien etsimistä myös vanhasta ja unohdetusta thai-uskonnosta. Sitä harjoitettiin jo ennen buddhalaisuuden tuloa ja se merkitsee syvimmiltääin kirkasta ja selkeää käsitystä jumaluuden, ihmisyyden ja luonnon välisestä yhteydestä.

Tohtori Koson Srisangin projekti ja kyläinstituutin toiminta perustuvat siis kansanviisaudelle.

Työ ei ole ollut helppoa. Viranomaiset ovat katsoneet karsaasti koulutusprojektia ja sen toimintaa on tarkkailtu. Kolmeen eri otteeseen kylässä on vieraillut kolmenkymmenen aseistetuun henkilön ryhmä, joka on kullakin kerralla viipynyt paikalla kolmen viikon ajan tarkoituksenaan tuhota tämä omapäinen aloitteellisuus. Projektia on kuitenkin vastoinkäymisistä huolimatta onnistuttu jatkamaan. Aseina ovat olleet nöyrä kärsivällisyys ja määrätietoinen sitoutuminen siihen, mitä pidetään oikeana. Aseellisia vierailuja ei ole tapahtunut enää vuoden 1988 jälkeen.

"'Thaimaa ei ole köyhä maa, vaikka niin monet ihmiset ovatkin köyhiä', Srisang sanoo. "Joillakin harvoilla on vain niin paljon ja enemmistöllä niin vähän. On kysymys syrjinnästä ja epäoikeudenmukaisuudesta."

\section{Yhteisöllä on oma filosofia}

Yhteisön toiminta perustuu viiden kohdan filosofiaan. Ensinnäkin rakkaus maahan ja ympäristöön sekä luonnon ja ihmisen yhteyden ymmärtäminen. Toiseksi käden taitojen kehittäminen ja työn tekeminen käsillä. Kolmanneksi sydämen ravitseminen säälillä ja myötätunnolla niin, että opittaisiin enemmän jakamaan kuin kilpailemaan. Neljänneksi ajattelun ja ymmärtämisen kehittäminen. Viidenneksi se, minkä perimätieto kertoo, että yksilö ja yhteisö ovat yhtä merkityksellisiä.

Päämääränä on yksinkertainen ja kulutuskriittinen elämäntapa ja laajan koulutuksen avulla saavutettava henkinen ja taloudellinen omaehtoisuus ja omavaraisuus. Laajaan talousohjel- maan kuuluu maanviljelyksen kehittäminen siten, että se mitä kulutetaan, tuotetaan itse. Teknisessä koulutuksessa pyritään tarkoituksen- mukaisuuteen. Se merkitsee esimerkiksi sitä, että instituutissa valmistetaan itse sellaisia työvälineitä, jotka pystytään myös itse korjaamaan ja huoltamaan. Tulevaisuudessa pyritään myös itse kehittämään uusia työvälineitä.

Instituutissa voi harjoittaa jonkin verran yliopistotason opintoja, esimerkiksi matematiikkaa, yhteiskuntatiedettä ja kieliä. Perusterveydenhuoltoa opiskellaan rinnakkain perinteisen luonnonlääkinnän kanssa. Lakitietoa opinto-ohjelmassa on sen verran, että opiskelijat oppivat ymmärtämään lakitekstiä ja kykenevät ajamaan omia ja muiden kylän asukkaiden asioita voidakseen taistella hyväksikäyttöä ja syrjintää vastaan.

Oman perinteisen kulttuurin ymmärtäminen ja eri taiteenlajien, esimerkiksi kansanmusiikin ja vanhojen tarinoiden tunteminen ovat keskeisellä sijalla.

Kaikessa opetuksessa korostetaan ihmisten eettistä rohkeutta sekä sitoutumista toimimaan sekä hengellisten, henkisten että poliittisten asioiden hyväksi. On kysymys sosiaalisen tietoisuuden herättämisestä sekä maailmanlaajuisen näkökulman avaamisesta.

Tohtori Koson Srisang sanoo, että hänen paluunsa omaan kotikylään merkitsee hänen erään elämänkehänsä umpeutumista. Hän haluaa elää yhdessä yhteisön muiden ihmisten kanssa ja jakaa heidän kokemuksensa ja kohtalonsa. Srisangin unelma on nähdä kyläinstituutti, jonka tehtävänä on kasvatus ja vaihtoehtoisen elämäntavana opiskelu: tulevien kymmenen vuoden kuluessa kehittyvä kyläyliopisto.

Mutta hän puhuu myös ihmiskunnan yhteisestä unelmasta ja yhteisestä polusta. Hän tarkoittaa sillä sitä, että kukin kohdallamme voimme olla parantamassa kasvatuksen kautta kaikkein heikoimmassa asemassa olevien lähimmäistemme asemaa ja rakentamassa maailmaa, jossa vallitsee rauha ja oikeudenmukaisuus.
Instituutin osoite: Phd Koson Srisang/ VITAL Nalao Village, Tambol Nonghai P.O. Box no. 1, Wapipathum Mahasarakham 44120 Thailand
Phd Koson Srisang P.O. Box 24 Chorakhebua Bangkok 10230, Thailand puh. (02)510-7287
Kuva vasemmalla: Silkkiperhosten toukista saatava silkkilanka on yksi köyhien koillisthaimaalaisten kylien käsityöelinkeinoista. (Kuva: Anneli Kajanto) 